\title{
Rapid Detection of Mycoplasma bovis, Staphylococcus aureus and Streptococcus agalactiae in Cattle Bulk Tank Milk in Cyprus and Relations with Somatic Cell Counts
}

\author{
Maria Liapi ${ }^{1,2}$, George Botsaris ${ }^{1, *(\mathbb{D})}$, Costas Arsenoglou ${ }^{2}$, Nikolas Markantonis ${ }^{1}$, Christodoulos Michael ${ }^{1}$, \\ Antonis Antoniou ${ }^{3}$ and Christodoulos Pipis ${ }^{2}$ \\ 1 Department of Agricultural Sciences, Biotechnology and Food Science, Cyprus University of Technology, \\ Limassol 3036, Cyprus; mliapi@vs.moa.gov.cy (M.L.); nicolas.markantonis@cut.ac.cy (N.M.); \\ ce.michael@edu.cut.ac.cy (C.M.) \\ 2 Cyprus Veterinary Services, 1417 Athalassas Av, Nicosia 1417, Cyprus; carsenoglou@vs.moa.gov.cy (C.A.); \\ hpipis@vs.moa.gov.cy (C.P.) \\ 3 Cyprus Institute of Neurology and Genetics, Nicosia 1683, Cyprus; a.antoniou@nipd.com \\ * Correspondence: george.botsaris@cut.ac.cy; Tel.: +357-25002582
}

Citation: Liapi, M.; Botsaris, G.; Arsenoglou, C.; Markantonis, N.; Michael, C.; Antoniou, A.; Pipis, C. Rapid Detection of Mycoplasma bovis, Staphylococcus aureus and Streptococcus agalactiae in Cattle Bulk Tank Milk in Cyprus and Relations with Somatic Cell Counts. Pathogens 2021, 10, 841 . https://doi.org/10.3390/

pathogens 10070841

Academic Editors: George Fthenakis and Maria Filippa Addis

Received: 16 June 2021

Accepted: 1 July 2021

Published: 4 July 2021

Publisher's Note: MDPI stays neutral with regard to jurisdictional claims in published maps and institutional affiliations.

Copyright: (c) 2021 by the authors. Licensee MDPI, Basel, Switzerland. This article is an open access article distributed under the terms and conditions of the Creative Commons Attribution (CC BY) license (https:// creativecommons.org/licenses/by/ $4.0 /)$.

\begin{abstract}
One hundred and seventy-seven (177) bulk tank milk samples were analyzed with a commercially available real-time polymerase chain reaction kit and 11 (6.21\%), 41 (23.16\%), and 58 (32.77\%) tested positive for Mycoplasma bovis, Staphylococcus aureus, and Streptococcus agalactiae, respectively. Statistical analysis revealed a significant relationship between the presence of $S$. aureus and S. agalactiae. Enumeration of somatic cells was performed in the same samples by flow cytometry. The somatic cell counts were found higher in S. aureus and S. agalactiae positive samples. No association was found between $M$. bovis presence and somatic cells counts. Low internal assay control $\mathrm{Ct}$ values were found to be related with high somatic cell counts. Noticeably, this is the first report for the presence of $M$. bovis in Cyprus. Therefore, its presence was confirmed by bulk tank milk culture, conventional PCR, and next generation sequencing. Furthermore, M. bovis was typed with multilocus sequencing typing and was allocated to sequence type 29 (ST 29). Real-time PCR in bulk tank milk samples is a useful tool to detect mammary infections, especially for neglected pathogens such as M. bovis.
\end{abstract}

Keywords: Bovine mastitis; Mycoplasma bovis; Staphylococcus aureus; Streptococcus agalactiae; somatic cells

\section{Introduction}

Mastitis is the most common disease of dairy cows, which results in economic losses to farmers and several animal welfare issues. Researchers and farmers have been making continuous efforts concerning mastitis detection, management, and prevention, since the beginning of modern dairy farming [1]. Mastitis is mainly caused by the bacterial species Staphylococcus aureus (S. aureus), Streptococcus agalactiae (S. agalactiae), Mycoplasma spp., Escherichia coli, Klebsiella spp., Enterobacter aerogenes, Streptococcus uberis, Serratia spp., Pseudomonas spp., Proteus spp. and other environmental Streptococci, and Enterobacter spp. [2-4]. S. agalactiae and S. aureus are considered to be the most significant contagious pathogens that can cause mastitis in cattle. Therefore, management control strategies have been developed for these pathogens. However, control still often depends on the use of antibiotics, which must be limited [1]. Mycoplasma bovis (M. bovis) is considered an emerging but overlooked cattle pathogen, which causes, in addition to mastitis, clinical disease with variable symptoms, including pneumonia, arthritis, genital disorders, keratoconjunctivitis, and otitis media [5]. Treatment of mastitis due to $M$. bovis with antibiotics is difficult and culling remains the most common recommendation [6]. 
Current research on gap analysis of $M$. bovis disease has highlighted the need for surveys to estimate the presence of $M$. bovis, since most of the available information is emanating from passive surveillance data [6]. The development of molecular methods, and specifically the introduction of the more recent probe based real-time PCR methods in bulk tank milk (BTM), has improved the sensitivity of mastitis pathogens detection compared to culture, whilst demonstrating also a high specificity [7-9]. So far, real-time PCR has been applied for the detection of mastitis pathogens in BTM only in a limited number of studies [10-12].

The presence of S. aureus and S. agalactiae in milk has also been additionally associated with elevated somatic cell counts (SCC), which have been also considered a useful tool for mastitis control programs [1]. In contrast, concerning M. bovis, recent studies suggest that SCC in milk are not sensitive enough to be used as herd level surveillance tools for mycoplasma mastitis and as a single basis for M. bovis mastitis control programs in farms [13-15].

A recent meta-analysis concludes that based on the current methods applied for the detection and identification of bacterial species, molecular methods are more sensitive than the traditional culture methods and should be considered as a diagnostic tool in future studies [2]. The real-time PCR assay used in this study includes an internal assay control (IAC), based on a ruminant housekeeping gene, which serves as an extraction and amplification control. It is suggested by the manufacturer that a low $\mathrm{Ct}$ value of the IAC may indicate a high somatic cell count in the milk sample tested. In case of negative results for the three pathogens, this information may additionally suggest an infection with other mastitis causing pathogens. However, no field study has been performed to confirm or reject this suggestion.

In Cyprus, there is no previous study describing the current situation regarding the presence of mastitis causing pathogens in raw milk. Considering all of the above, the objectives of this study were: (1) to detect $S$. aureus, S. agalactiae and M. bovis in cattle BTM samples using real-time PCR and estimate their prevalence; (2) to investigate the correlations of their presence or absence; (3) to evaluate BTM SCC in relation to the realtime PCR results for these three pathogens; and (4) to investigate the correlation of the $\mathrm{Ct}$ values of the internal assay control (IAC) of the real-time PCR assay and the SCC.

\section{Results}

\subsection{Real-Time PCR Results}

\subsubsection{Prevalence of Pathogens}

All detectable species by the real-time PCR kit were identified. S. agalactiae was the most common pathogen found in 58/177 BTM samples (32.77\%; 95\% CI: 25.91-40.21\%), followed by S. aureus in $41 / 177$ BTM samples $(23.16 \%$; $95 \%$ CI: $17.16-30.08 \%)$ and M. bovis in 11/177 BTM samples (6.21\%; 95\% CI: $3.14-10.85 \%)$. S. agalactiae was present in BTM samples from all five districts, $S$. aureus was not found in BTM samples from one district (Paphos) and M. bovis was not found in BTM samples from two districts, (Limassol and Paphos) (see Table 1).

Table 1. Prevalence of M. bovis, S. aureus and S. agalactiae in BTM samples in Cyprus.

\begin{tabular}{|c|c|c|c|c|c|c|c|c|c|}
\hline \multirow[b]{3}{*}{ District } & \multirow[b]{3}{*}{$\begin{array}{c}\text { No. of } \\
\text { Existing } \\
\text { Farms }\end{array}$} & \multirow[b]{3}{*}{$\begin{array}{l}\text { No. of } \\
\text { BTM } \\
\text { Samples } \\
\text { Collected }\end{array}$} & \multirow[b]{3}{*}{$\begin{array}{c}\% \\
\text { Sampling } \\
\text { Coverage }\end{array}$} & \multicolumn{6}{|c|}{ Real-Time PCR Results } \\
\hline & & & & \multicolumn{2}{|c|}{ M. bovis } & \multicolumn{2}{|c|}{ S. aureus } & \multicolumn{2}{|c|}{ S. agalactiae } \\
\hline & & & & $\begin{array}{c}\text { No. of } \\
\text { Positive } \\
\text { BTM } \\
\text { Samples }\end{array}$ & $\begin{array}{c}\text { Positive \% } \\
\text { (95\% CI) }\end{array}$ & $\begin{array}{l}\text { Number of } \\
\text { Positive } \\
\text { BTM } \\
\text { Samples }\end{array}$ & $\begin{array}{l}\text { Positive \% } \\
\text { (95\% CI) }\end{array}$ & $\begin{array}{c}\text { No. of } \\
\text { Positive } \\
\text { BTM } \\
\text { Samples }\end{array}$ & $\begin{array}{c}\text { Positive \% } \\
\text { (95\% CI) }\end{array}$ \\
\hline Nicosia & 93 & 63 & 67.74 & 3 & $\begin{array}{c}4.76 \\
(0.99-13.29)\end{array}$ & 11 & $\begin{array}{c}17.46 \\
(9.05-29.1)\end{array}$ & 17 & $\begin{array}{c}26.98 \\
(16.57-39.65)\end{array}$ \\
\hline Limassol & 11 & 10 & 90.91 & 0 & 0 & 6 & $\begin{array}{c}60 \\
(26.24-87.84)\end{array}$ & 6 & $\begin{array}{c}60 \\
(8.29-28.52)\end{array}$ \\
\hline
\end{tabular}


Table 1. Cont.

\begin{tabular}{|c|c|c|c|c|c|c|c|c|c|}
\hline \multirow[b]{3}{*}{ District } & \multirow[b]{3}{*}{$\begin{array}{c}\text { No. of } \\
\text { Existing } \\
\text { Farms }\end{array}$} & \multirow[b]{3}{*}{$\begin{array}{c}\text { No. of } \\
\text { BTM } \\
\text { Samples } \\
\text { Collected }\end{array}$} & \multirow[b]{3}{*}{$\begin{array}{c}\% \\
\text { Sampling } \\
\text { Coverage }\end{array}$} & \multicolumn{6}{|c|}{ Real-Time PCR Results } \\
\hline & & & & \multicolumn{2}{|c|}{ M. bovis } & \multicolumn{2}{|c|}{ S. aureus } & \multicolumn{2}{|c|}{ S. agalactiae } \\
\hline & & & & $\begin{array}{l}\text { No. of } \\
\text { Positive } \\
\text { BTM } \\
\text { Samples }\end{array}$ & $\begin{array}{l}\text { Positive \% } \\
\text { (95\% CI) }\end{array}$ & $\begin{array}{c}\text { Number of } \\
\text { Positive } \\
\text { BTM } \\
\text { Samples }\end{array}$ & $\begin{array}{l}\text { Positive \% } \\
\text { (95\% CI) }\end{array}$ & $\begin{array}{l}\text { No. of } \\
\text { Positive } \\
\text { BTM } \\
\text { Samples }\end{array}$ & $\begin{array}{l}\text { Positive \% } \\
\text { (95\% CI) }\end{array}$ \\
\hline Larnaca & 79 & 68 & 86.08 & 5 & $\begin{array}{c}7.35 \\
(2.43-16.33)\end{array}$ & 19 & $\begin{array}{c}27.94 \\
(17.73-40.15)\end{array}$ & 25 & $\begin{array}{c}36.76 \\
(25.39-49.33)\end{array}$ \\
\hline Famagusta & 40 & 32 & 80 & 3 & $\begin{array}{c}9.38 \\
(1.98-25.02)\end{array}$ & 5 & $\begin{array}{c}15.63 \\
(5.28-32.79)\end{array}$ & 8 & $\begin{array}{c}25 \\
(11.46-43.4)\end{array}$ \\
\hline Paphos & 5 & 4 & 80 & 0 & 0 & 0 & 0 & 2 & $\begin{array}{c}50 \\
(6.76-93.24)\end{array}$ \\
\hline Totals & 228 & 177 & 77.63 & 11 & $\begin{array}{c}6.21 \\
(3.14-10.85)\end{array}$ & 41 & $\begin{array}{c}23.16 \\
(17.16-30.08)\end{array}$ & 58 & $\begin{array}{c}32.77 \\
(25.91-40.21)\end{array}$ \\
\hline
\end{tabular}

\subsubsection{Correlation of Presence or Absence between Pathogens}

The comparisons of the results between the three pathogens are presented in Table 2 and were tested for statistical significance using the chi-squared test. The chi-square test between $M$. bovis and the other two pathogens did not fulfill the minimum expected cell frequency assumption, because of the low number of positive samples and, therefore, a safe conclusion could not have been drawn from this. However, the presence of $S$. aureus was low to moderately correlated with the presence of $S$. agalactiae in the BTM samples tested (Pearson's correlation coefficient $=0.444$ ). Following this, binary logistic regression was applied, and the likelihood of a S. agalactiae positive BTM sample to be found also positive for S. aureus was 8.917 (OR 8.917; 95\% CI: 4.055 to 19.608) times higher than the likelihood of a $S$. agalactiae negative BTM sample to be found also positive for $S$. aureus.

Table 2. Comparison of mastitis pathogen detection in BTM samples.

\begin{tabular}{cccccc}
\hline & \multicolumn{2}{c}{ S. agalactiae } & \multicolumn{2}{c}{ M. bovis } \\
\cline { 2 - 5 } & $\begin{array}{c}\text { Negative } \\
\text { BTM } \\
\text { Samples }\end{array}$ & $\begin{array}{c}\text { Positive } \\
\text { BTM } \\
\text { Samples }\end{array}$ & $\begin{array}{c}\text { Negative } \\
\text { BTM } \\
\text { Samples }\end{array}$ & $\begin{array}{c}\text { Positive } \\
\text { BTM } \\
\text { Samples }\end{array}$ \\
\hline \multirow{2}{*}{ M. bovis } & $\begin{array}{c}\text { Negative } \\
\text { BTM samples } \\
\text { Positive BTM } \\
\text { samples }\end{array}$ & 107 & 29 & 128 & 8 \\
& $\begin{array}{c}\text { Negative } \\
\text { BTM samples } \\
\text { Positive BTM } \\
\text { samples }\end{array}$ & 110 & 29 & 38 & 3 \\
\hline
\end{tabular}

\subsubsection{Comparison of SCC with the Presence and Absence of Each Pathogen}

The independent samples t-test was conducted to compare SCC counts with the presence or absence of each pathogen. There was significant difference in SCC between positive $S$. aureus $\mathrm{BTM}$ samples (mean $=5.75, \mathrm{SD}=0.26$ ) and negative $S$. aureus $\mathrm{BTM}$ samples (mean $=5.54, \mathrm{SD}=0.28, p=0.00)$. Overall, nine-point one percent $(9.1 \%)$ of the variability in BTM SCC was explained by the S. aureus real-time PCR status (positive/negative) of the BTM sample (eta squared $=0.091$ ).

Regarding S. agalactiae, a significant difference in SCC was observed between positive $($ mean $=5.75, \mathrm{SD}=0.25)$ and negative BTM samples (mean $=5.52, \mathrm{SD}=0.27, p=0.00)$. More specifically, thirteen-point eight percent (13.8\%) of the variability in BTM SCC was explained by the S. agalactiae real-time PCR status (positive/negative) of the BTM sample tested (eta squared 0.138). For M. bovis, no significant difference was observed between the SCC of $M$. bovis positive $(\mathrm{M}=5.63, \mathrm{SD}=0.11)$ and negative samples (mean $=5.59, \mathrm{SD}=0.29$, $p=0.634)$. 


\subsubsection{Correlation between the Ct Values of the IAC and the SCC}

Following the statistical analysis, IAC Ct values and SCC were found to be significantly related variables with a Pearson's correlation coefficient of 0.549 .

\subsubsection{M. bovis Isolation, Identification and MLST Typing}

The isolation of M. bovis from the dairy herds in Cyprus was never previously reported. Thus, following the positive PCR results, samples from positive herds were cultured in solid and liquid media in an attempt to isolate and characterize the pathogen for the first time. Three samples developed colonies in the solid media with the characteristic fried-egg appearance of the class mollicutes. DNA was extracted from the liquid media and PCR was performed for M. bovis and Mycoplasma spp. Two out of the three isolates were confirmed to be Mycoplasma spp. and specifically M. bovis. The other isolate was negative to both Mycoplasma spp. and M. bovis PCR.

DNA was further sequenced and tested for species identification with CCmetagen and the M. bovis DNA was tested with pubMLST. The cultured sample that was negative for Mycoplasma spp. and M. bovis DNA, was identified as Acholeplasma laidlawii, while both M. bovis DNA were species confirmed and allocated to M. bovis ST29.

\section{Discussion}

Bacterial culture of milk samples on blood agar plates has for many years been the standard method for isolation of mastitis pathogens, despite the fact that some pathogens, such as Mycoplasma spp., are not detected because they require specific media and growth conditions [16]. The sensitivity of BTM culture for mastitis pathogens is generally considered low and multiple BTM sampling is recommended to estimate the true prevalence of mastitis-causing pathogens $[17,18]$.

The more recently developed probe based real-time PCR assays for detection of pathogens in BTM, have improved the sensitivity of mastitis pathogens detection compared to culture with a high specificity and allow the simultaneous detection of fastidious organisms, such as M. bovis $[8,9,19]$.

The current literature review reveals three different studies which applied probe based real-time PCR in BTM for mastitis pathogens. One study in Canada, which includes the detection of the three mastitis pathogens examined here (M. bovis, S. aureus, and $S$. agalactiae) and two other studies, in Denmark and in three provinces of China, report the detection of S. aureus and S. agalactiae [10-12]. Comparatively, the prevalence of M. bovis in BTM found in this study $(6.25 \%)$ was higher than the one found in BTM in Canada $(0.53 \%)$. Concerning S. aureus, the prevalence in BTM in Cyprus $(23.16 \%)$ was found to be lower than those reported in Canada (46\%), Denmark (91\%), and China (50.1\%). For S. agalactiae, the prevalence in BTM $(32.77 \%)$ was much higher than those reported in Canada $(0.26 \%)$ and Denmark (7\%) and much lower than the one found in China (92.2\%). A more recent study in Egypt reports a total prevalence of $35.9 \%$ for S. aureus in cattle and additionally highlights the need to further investigate this pathogen for antimicrobial resistance [20]. This study did not look at the antimicrobial resistance patterns of the three mastitis pathogens detected, as the primary objective was to detect and estimate the extent of the presence of the pathogens tested. In the future, antimicrobial resistance should be addressed as it is a major concern regarding the public health issues involved with the development of antimicrobial resistance in the animal population and the food chain in general. Dairy farming in Cyprus has grown significantly over recent years, with the reported population of 28825 lactating animals in 2015 rising to 38473 in 2020 [21]. 
The present study shows that mastitis prevention control programs should be considered in Cyprus, as the population of animals increases and farming becomes more intensive. The low prevalence of S. agalactiae in BTM in countries like Denmark and Canada most probably reflects the impact of application of $S$. agalactiae prevention programs or the generally good management practices that are adopted for mastitis in these countries [12,22]. Additionally, the levels of S. aureus and S. agalactiae in China could be attributed to the different farming practices adopted there, due to the weakness of applying unified and efficient good management practices and control programs [11]. Concerning the high prevalence of S. aureus in BTM, it should be noted that contamination of BTM samples with $S$. aureus can lead to false positive results because $S$. aureus, apart from the udder, may have an environmental source in contrast to $S$. agalactiae, which is an obligate mammary pathogen [23]. The results of this preliminary study in Cyprus demonstrate a lower prevalence of $S$. aureus compared to the other studies but a higher $S$. agalactiae prevalence. This finding should alert the dairy industry stakeholders towards introducing control programs in an attempt to reduce $S$. agalactiae infection in dairy herds.

Overall, the presence of S. aureus and S. agalactiae in BTM in Cyprus was an expected finding since their presence is a common finding in milk samples from clinical cases of mastitis (veterinary services-unreported data). In contrast, the presence of $M$. bovis in Cyprus was unknown until this study. Therefore, samples from positive herds were cultured to isolate the pathogen and verify its presence in Cyprus. PCR identification and next generation sequencing of the isolates were additionally performed to confirm the presence of this pathogen and type it with MLST.

A recent study comparing the performance of the two MLST schemes available for M. bovis concludes that the originally used pubMLST scheme offers higher discriminatory power to that provided by the Weybridge scheme [24]. According to the pubMLST database, the $M$. bovis ST type 29 was identified in this study, which has also been found in five isolates from Israel and one isolate from an animal being quarantined in Israel after being imported from Hungary [24]. However, the dominant $M$. bovis MLST type in Israel was found to be ST10 [25]. The Acholeplasma laidlawii isolate, which was also identified, is generally considered a non-pathogenic contaminant, occasionally found in cattle milk samples [26]. More research is needed, which will include more isolates to better describe the distribution of the M. bovis and other Mycoplasma spp. strains in Cyprus.

Following the analysis of the results, the likelihood of a S. agalactiae positive BTM sample to be found also positive for S. aureus, was 8.917 times higher than the likelihood of a S. agalactiae negative BTM sample to be found also positive for $S$. aureus. The correlation between these two pathogens could be explained from common epidemiological risk factors and confirms other published suggestions [27]. In the present study, no conclusion could be drawn for correlations of $M$. bovis with the other two pathogens, due to the low number of positive $M$. bovis BTM samples. However, previous research suggests that Mycoplasma spp. must have a distinct epidemiology and a different set of risk factors than the more traditional contagious pathogens S. aureus and S. agalactiae [27].

This study confirms the previously reported association of S. aureus and S. agalactiae real-time PCR detection with elevated SCC in BTM samples [12]. Concerning M. bovis and SCC, earlier studies suggested that infection with M. bovis can elevate SCC in individual and BTM samples [28]. Therefore, the generally recommended rule to control intramammary infections due to M. bovis is sampling of cows with high SCC in milk [29]. However, more recent studies in individual milk suggest that due to the finding that not all culture positive animals show higher SCC, if SCC are used as the single basis for a mastitis control program in a farm, they may lead to the omission of M. bovis positive animals. Consequently, concerning SCC in BTM, it is suggested that SCC are not sensitive enough to be used as a surveillance tool for mycoplasma mastitis detection at herd level [13-15]. In the current study, no statistically significant association was found between $M$. bovis presence and SCC in BTM samples despite the fact that SCC counts were higher in M. bovis positive BTM samples. 
Finally, the present study confirms an association between the IAC Ct values of the real-time PCR assay and the somatic cell counts. This finding can be a useful indicator in case of negative results for the three mastitis pathogens. The low $\mathrm{Ct}$ values in these cases, suggest the need for further diagnostic investigation of other mastitis pathogens. Subclinical mastitis caused by pathogens, such as S. aureus, S. agalactiae, and especially $M$. bovis, has a worldwide animal welfare and a public health significance [2]. The results from this investigation suggest that there is an urgent need to reduce the prevalence of mastitis pathogens by ensuring scientific farm management practices, proper feeding techniques, and therapeutic interventions. These measures could result in enhanced profits in a fast-growing dairy sector and improves animal and human health.

\section{Materials and Methods}

\subsection{Cattle Population}

During the sampling period, Cyprus had a total of 238 dairy cattle herds, which corresponded to a population of 23,093 animals in lactation at the time of sampling. Herd size was ranging between 20 and 2974 cows. All of the bovine animals were registered on the official database of the Cyprus Veterinary Services (see Table 1).

\subsection{Sampling of BTM}

One hundred and seventy-seven (177) BTM samples were collected from 177 dairy cattle herds through the mandatory milk quality surveillance scheme. Sampling was performed between February 2018 and May 2018. The samples were collected by the BTM truck drivers using automated truck milk collection equipment, in $40 \mathrm{~mL}$ sterile containers with $0.133 \mathrm{~mL}$ azidiol and stored at $4{ }^{\circ} \mathrm{C}$ until they were transferred to the laboratory for enumeration of somatic cells. Samples were then frozen at $-20^{\circ} \mathrm{C}$ and thawed prior to further processing. The 177 sampled herds corresponded to a population of 18,744 animals in lactation at the time of sampling. Herd size ranged between 24 and 1773 cows.

\subsection{Enumeration of Somatic Cells}

Enumeration of somatic cells in samples was determined by flow cytometry, using the Fossomatic ${ }^{\mathrm{TM}}$ FC instrument (Foss, Hillerød, Denmark). SCC were measured in cells $/ \mathrm{mL}$.

\subsection{DNA Extraction and Real-Time PCR}

The DNA extraction and the real-time PCR were performed with DNeasy Mastitis Mini Kit, Qiagen and Bactotype Mastitis HP3 PCR Kit (Qiagen), according to the manufacturer's instructions. The Ct- value cut-off was set to be $<35$ for positive result. The thermal cycler used was the iQ5 (Bio-Rad).

\subsection{M. bovis Isolation}

Isolation of M. bovis was performed on Mycoplasma Experience solid and liquid Media (RH2 9BY Reigate, Surrey, UK), as previously described [30]. Colonies were seen using a stereo microscope (Zeiss stemi SV 11).

\subsection{PCR's and Next Generation Sequencing}

For the next generation sequencing, DNA was extracted from the liquid media using the QIAamp UCP Pathogen Mini Kit (Qiagen). The PCR for the M. bovis (urvc gene) and the Mycoplasma spp. genus specific PCR were performed as described in the literature [31,32]. Next generation sequencing was performed with the i-Seq (Illumina) sequencer using the Nextera DNA Flex Library Preparation (Illumina). Species identification was performed using the CCmetagen [33,34]. MLST was performed using pubMLST [24]. 
The genomes described in this manuscript have been deposited in the National Center for Biotechnology Information (NCBI) under the project accession number PRJNA673092 with accession numbers SRR12937688, SRR12937689 and SRR12937690.

\subsection{Statistical Analysis}

The statistical analysis was performed using the SPSS 23 software (SPSS Inc., Chicago, IL, USA). Confidence intervals were estimated with the exact method [35]. SCC values and IAC Ct values were normalized by log transformation.

\section{Conclusions}

The real-time PCR in BTM is a useful, practical tool to detect mastitis pathogens in BTM. This study estimated a higher prevalence of S. agalactiae than S. aureus in Cypriot BTM samples from dairy cattle farms, and revealed the presence of M. bovis on the island, a neglected mastitis pathogen. Elevated SCC were confirmed to be related with real-time PCR detection of S. aureus and S. agalactiae, however they seem to have low usefulness for M. bovis infection. When real-time PCR is used as a diagnostic tool, low IAC Ct values can indicate a high SCC and even if a sample is negative for the pathogens tested, the presence of other mastitis pathogens should be investigated. Next generation sequencing is an extremely useful tool for one step identification or MLST typing of isolates, especially for challenging organisms such as mycoplasmas and Acholeplasmas.

Author Contributions: G.B., M.L. and C.P. designed the study. M.L. and C.A. performed the somatic cell counts and the culture experiments. M.L., G.B., N.M. and C.M. performed the molecular identification experiments. M.L., G.B. and A.A. performed the sequencing experiments. M.L., G.B. and A.A. drafted the manuscript and all authors discussed the results and commented on the manuscript. All authors have read and agreed to the published version of the manuscript.

Funding: This work was partly supported by a startup grand warded to GB by Cyprus University of Technology (Reference number 200122). Open access fees were covered by CUT Open Access Author Fund.

Institutional Review Board Statement: Not applicable.

Informed Consent Statement: Not applicable.

Data Availability Statement: Not applicable.

Acknowledgments: The authors would like to thank Elena Orphanou (Veterinary Services) for her excellent technical assistance.

Conflicts of Interest: The authors declare no conflict of interest.

\section{References}

1. Ruegg, P.L. A 100-Year Review: Mastitis detection, management, and prevention. J. Dairy Sci. 2017, 100, 10381-10397. [CrossRef]

2. Krishnamoorthy, P.; Suresh, K.P.; Jayamma, K.S.; Shome, B.R.; Patil, S.S.; Amachawadi, R.G. An Understanding of the Global Status of Major Bacterial Pathogens of Milk Concerning Bovine Mastitis: A Systematic Review and Meta-Analysis (Scientometrics). Pathogens 2021, 10, 545. [CrossRef] [PubMed]

3. Erskine, R.J.; Bartlett, P.C.; VanLente, J.L.; Phipps, C.R. Efficacy of systemic ceftiofur as a therapy for severe clinical mastitis in dairy cattle. J. Dairy Sci. 2002, 85, 2571-2575. [CrossRef]

4. Quinn, P.J.; Carter, M.E.; Markey, B.K.; Carter, G.R. Clinical Veterinary Microbiology; Harcourt Publishers: Richmond, VA, USA, 2002; pp. 331-344.

5. Calcutt, M.J.; Lysnyansky, I.; Sachse, K.; Fox, L.K.; Nicholas, R.A.J.; Ayling, R.D. Gap analysis of Mycoplasma bovis disease, diagnosis and control: An aid to identify future development requirements. Transbound. Emerg. Dis. 2018, 65, 91-109. [CrossRef] [PubMed]

6. Nicholas, R.; Fox, L.K.; Lysnyasky, I. Mycoplasma mastitis in cattle. To cull or not to cull. Vet. J. 2016, 216, 142-147. [CrossRef] [PubMed] 
7. Koskinen, M.T.; Holopainen, J.; Pyörälä, S.; Bredbacka, P.; Pitkälä, A.; Barkema, H.W.; Bexiga, R.; Roberson, J.; Solverod, L.; Piccinini, R.; et al. Analytical specificity and sensitivity of a real-time polymerase chain reaction assay for identification of bovine mastitis pathogens. J. Dairy Sci. 2009, 92, 952-959. [CrossRef]

8. Mweu, M.M.; Toft, N.; Katholm, J.; Nielsen, S.S. Evaluation of two herd-level diagnostic tests for Streptococcus agalactiae using a latent class approach. Vet. Microbiol. 2012, 159, 181-186. [CrossRef]

9. Parker, A.M.; Sheehy, P.A.; Hazelton, M.S.; Bosward, K.L.; House, J.K. A review of mycoplasma diagnostics in cattle. J. Vet. Intern. Med. 2018, 32, 1241-1252. [CrossRef]

10. Bauman, C.A.; Barkema, H.W.; Dubuc, J.; Keefe, G.P.; Kelton, D.F. Canadian National Dairy Study: Herd-level milk quality. J. Dairy Sci. 2018, 101, 2679-2691. [CrossRef] [PubMed]

11. Bi, Y.; Wang, Y.J.; Qin, Y.; Vallverdú, R.G.; García, J.M.; Sun, W.; Li, S.; Cao, Z.C. Prevalence of bovine mastitis pathogens in bulk tank milk in China. PLoS ONE 2016, 11, e0155621. [CrossRef]

12. Katholm, J.; Bennedsgaard, T.W.; Koskinen, M.T.; Rattenborg, E. Quality of bulk tank milk samples from Danish dairy herds based on real-time polymerase chain reaction identification of mastitis pathogens. J. Dairy Sci. 2012, 95, 5702-5708. [CrossRef]

13. Hazelton, M.S.; Morton, J.M.; Parker, A.M.; Sheehy, P.A.; Bosward, K.L.; Malmo, J.; House, J.K. Whole dairy herd sampling to detect subclinical intramammary Mycoplasma bovis infection after clinical mastitis outbreaks. Vet. Microbiol. 2020, $244,108662$. [CrossRef]

14. Pinho, L.; Thompson, G.; Machado, M.; Carvalheira, J. Management practices associated with the bulk tank milk prevalence of Mycoplasma spp. in dairy herds in Northwestern Portugal. Prev. Vet. Med. 2013, 108, 21-27. [CrossRef] [PubMed]

15. Timonen, A.A.E.; Katholm, J.; Petersen, A.; Mõtus, K.; Kalmus, P. Within-herd prevalence of intramammary infection caused by Mycoplasma bovis and associations between cow udder health, milk yield, and composition. J. Dairy Sci. 2017, 100, 6554-6561. [CrossRef] [PubMed]

16. Adkins, P.R.F.; Middleton, J.R. Methods for Diagnosing Mastitis. Vet. Clin. N. Am. Food Anim. 2018, 34, 479-491. [CrossRef] [PubMed]

17. Riekerink, R.G.M.O.; Barkema, H.W.; Veenstra, S.; Poole, D.E.; Dingwell, R.T.; Keefe, G.P. Prevalence of contagious mastitis pathogens in bulk tank milk in Prince Edward Island. Can. Vet. J. 2006, 47, 567-572.

18. Wilson, D.J.; Goodell, G.; Justice-Allen, A.; Smith, S.T. Herd-level prevalence of Mycoplasma spp mastitis and characteristics of infected dairy herds in Utah as determined by a statewide survey. J. Am. Vet. Med. Assoc. 2009, 235, 749-754. [CrossRef]

19. Boonyayatra, S.; Fox, L.K.; Besser, T.E.; Sawant, A.; Gay, J.M.; Raviv, Z. A PCR assay and PCR-restriction fragment length polymorphism combination identifying the 3 primary Mycoplasma species causing mastitis. J. Dairy Sci. 2012, 95, 196-205. [CrossRef]

20. Algammal, A.M.; Enany, M.E.; El-Tarabili, R.M.; Ghobashy, M.O.I.; Helmy, Y.A. Prevalence, Antimicrobial Resistance Profiles, Virulence and Enterotoxins-Determinant Genes of MRSA Isolated from Subclinical Bovine Mastitis in Egypt. Pathogens 2020, 9 , 362. [CrossRef]

21. Animal Identification and Registration System, 2015-2020, Veterinary Services, Athalassa 1417, Nicosia. Available online: http:/ / www.agriconsultingeurope.be/en/animal-identification-and-registration-system (accessed on 1 July 2021).

22. Aghamohammadi, M.; Haine, D.; Kelton, D.F.; Barkema, H.W.; Hogeveen, H.; Keefe, G.P.; Dufour, S. Herd-level mastitisassociated costs on Canadian dairy farms. Front. Vet. Sci. 2018, 5, 1-12. [CrossRef]

23. Keefe, G. Update on control of Staphylococcus aureus and Streptococcus agalactiae for management of mastitis. Vet. Clin. N. Am. Food Anim. 2012, 28, 203-216. [CrossRef] [PubMed]

24. Register, K.B.; Lysnyansky, I.; Jelinski, M.D.; Boatwright, W.D.; Waldner, M.; Bayles, D.O.; Pilo, P.; Alt, D.P. Comparison of two multilocus sequence typing schemes for Mycoplasma bovis and revision of the PubMLST reference method. J. Clin. Microbiol 2020, 58, e00283-20. [CrossRef] [PubMed]

25. Lysnyansky, I.; Freed, M.; Rosales, R.S.; Mikula, I.; Khateb, N.; Gerchman, I.; van Straten, M.; Levisohn, S. An overview of Mycoplasma bovis mastitis in Israel (2004-2014). Vet. J. 2016, 207, 180-183. [CrossRef]

26. Boonyayatra, S.; Fox, L.K.; Gay, J.M.; Sawant, A.; Besser, T.E. Discrimination between Mycoplasma and Acholeplasma species of bovine origin using digitonin disc diffusion assay, nisin disc diffusion assay, and conventional polymerase chain reaction. J. Vet. Diagn. Invest. 2012, 24, 7-13. [CrossRef]

27. Fox, L.K.; Hancock, D.D.; Mickelson, A.; Britten, A. Bulk tank milk analysis: Factors associated with appearance of Mycoplasma sp. in milk. J. Vet. Med. 2003, 50, 235-240. [CrossRef]

28. Ghadersohi, A.; Hirst, R.G.; Forbes-Faulkener, J.; Coelen, R.J. Preliminary studies on the prevalence of Mycoplasma bovis mastitis in dairy cattle in Australia. Vet. Microbiol. 1999, 65, 185-194. [CrossRef]

29. Dudek, K.; Nicholas, R.A.J.; Szacawa, E.; Bednarek, D. Mycoplasma bovis infections-Occurrence, diagnosis and control. Pathogens 2020, 9, 640 .

30. Nicholas, R.; Ayling, R.; McAuliffe, L. Isolation and Growth of Mycoplasmas from Ruminants; Mycoplasma Diseases of Ruminants; CABI: Wallingford, UK, 2008; Volume 1, pp. 3-14.

31. Subramaniam, S.; Bergonier, D.; Poumarat, F.; Capaul, S.; Schlatter, Y.; Nicolet, J.; Frey, J. Species identification of Mycoplasma bovis and Mycoplasma agalactiae based on the uvrC genes by PCR. Mol. Cell. Probes 1998, 12, 161-169. [CrossRef]

32. van Kuppeveld, F.J.M.; Johansson, K.E.; Galama, J.M.D.; Kissing, J.; Bölske, G.; van der Logt, J.T.M.; Melchers, W.J.G. Detection of mycoplasma contamination in cell cultures. Appl. Environ. Microbiol. 1994, 60, 149-152. [CrossRef] [PubMed] 
33. Clausen, P.T.L.C.; Aarestrup, F.M.; Lund, O. Rapid and precise alignment of raw reads against redundant databases with KMA. BMC Bioinform. 2018, 19, 1-8. [CrossRef]

34. Marcelino, V.R.; Clausen, P.T.L.C.; Buchmann, J.P.; Wille, M.; Iredell, J.R.; Meyer, W.; Lund, O.; Sorrell, T.C.; Holmes, E.C. CCMetagen: Comprehensive and accurate identification of eukaryotes and prokaryotes in metagenomic data. Genome Biol. 2020, 21, 103. [CrossRef] [PubMed]

35. Sakakibara, I.; Haramo, E.; Muto, A.; Miyajima, I.; Kawasaki, Y. Comparison of Five Exact Confidence Intervals for the Binomial Proportion. Am. J. Biostat. 2014, 4, 11-20. [CrossRef] 